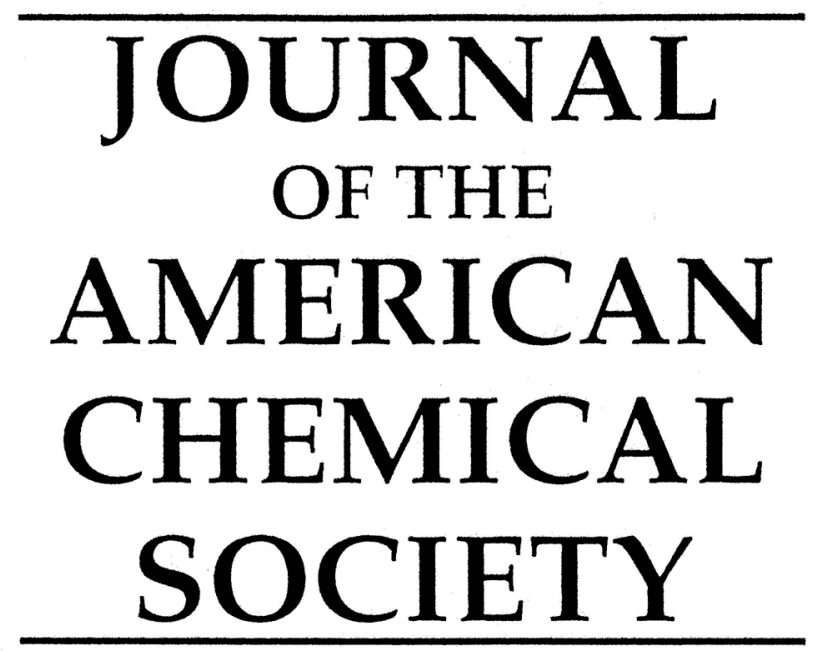

\title{
Can Multivalency Be Expressed Kinetically? The Answer is Yes
}

Jovica D. Badjić, Stuart J. Cantrill, and J. Fraser Stoddart*

California NanoSystems Institute, and

Department of Chemistry and Biochemistry, University of California, Los Angeles, 405 Hilgard Avenue, Los Angeles, California 90095-1569

\section{Supporting Information}

\section{Revised Version}

\begin{tabular}{|l|}
\hline \multicolumn{1}{|c|}{ Correspondence Address } \\
\hline Dr J Fraser Stoddart \\
Department of Chemistry and Biochemistry \\
University of California, Los Angeles \\
405 Hilgard Avenue \\
Los Angeles, CA 90095-1569 (USA) \\
Tel: Int. code +(310) 206-7078 \\
Email: stoddart@ chem.ucla.edu \\
\hline
\end{tabular}


The preparation of $[1]\left[\mathrm{PF}_{6}\right]_{6}$ was completed (Scheme S1) in four steps in $7.5 \%$ overall yield. Reduction $\left(\mathrm{NaBH}_{4}\right)$ of $\mathbf{3}$ yielded triol $\mathbf{4}$ which was converted $\left(\mathrm{NCS} / \mathrm{Ph}_{3} \mathrm{P} / \mathrm{THF}\right)$ into the trischloride $\mathbf{5}$. Reaction of 5 with 4,4'-bipyridine, followed by counterion exchange $\left(\mathrm{NH}_{4} \mathrm{PF}_{6} / \mathrm{MeOH} / \mathrm{H}_{2} \mathrm{O}\right)$, yielded the trifurcated salt $[6]\left[\mathrm{PF}_{6}\right]_{3}$ which was converted subsequently, into $[\mathbf{1}]\left[\mathrm{PF}_{6}\right]_{6}$ in a reaction with $p$ methyl benzylbromide, followed once again by counterion exchange.

General. All chemicals were purchased from Aldrich and were used without further purification. Column chromatography was performed on silica gel 60 (Merck $40-60 \mathrm{~nm}, 230-400$ mesh). Melting points were determined on an Electrothermal 9200 apparatus and are reported uncorrected. ${ }^{1} \mathrm{H}$ and ${ }^{13} \mathrm{C}$ NMR spectra were recorded on Bruker Avance-500 spectrometer at 500 and $125 \mathrm{MHz}$, respectively. The chemical shifts are expressed as $\delta$ values and the coupling constants $(J)$ are in hertz $(\mathrm{Hz})$. The following abbreviations were used for signal multiplicities: s, singlet; $\mathrm{d}$, doublet; t, triplet; and $\mathrm{m}$, multiplet. Fast atom bombardment mass spectrometry (FABMS) was performed on a VG ZAB-SE mass spectrometer, equipped with a krypton primary atom beam using a 3-nitrobenzyl alcohol matrix. Electron impact mass spectra (EI-MS) were obtained from a VB Prospec mass spectrometer.

4: $\mathrm{NaBH}_{4}(1.5 \mathrm{~g}, 38.4 \mathrm{mmol})$ was added portionwise to a solution of $\mathbf{3}(1.0 \mathrm{~g}, 2.6 \mathrm{mmol})$ in anhydrous $\mathrm{THF} / \mathrm{MeOH}(5: 1,90 \mathrm{~mL})$ at room temperature. The reaction mixture was left to stir overnight. The solvent was evaporated off under reduced pressure, and the remaining solid was partitioned between a saturated aqueous solution of $(50 \mathrm{~mL}) \mathrm{NaCl}$ and $\mathrm{THF}(200 \mathrm{~mL})$. The aqueous layer was then extracted with an additional portion of THF $(50 \mathrm{~mL})$. The THF layers were combined, dried $\left(\mathrm{MgSO}_{4}\right)$, filtered, and concentrated under reduced pressure to yield $4(650 \mathrm{mg}, 64 \%)$ as a beige sticky solid. ${ }^{1} \mathrm{H}$ NMR $\left(500 \mathrm{MHz}, \mathrm{CD}_{3} \mathrm{SOCD}_{3}\right) \delta 4.56(\mathrm{~d}, J=5 \mathrm{~Hz}, 6 \mathrm{H}), 5.23(\mathrm{t}, J=5 \mathrm{~Hz}, 3 \mathrm{H}), 7.44$ 
$(\mathrm{d}, J=8 \mathrm{~Hz}, 6 \mathrm{H}), 7.81(\mathrm{~d}, J=8 \mathrm{~Hz}, 6 \mathrm{H}), 7.84(\mathrm{~s}, 3 \mathrm{H}) ;{ }^{13} \mathrm{C} \mathrm{NMR}\left(125 \mathrm{MHz}, \mathrm{CD}_{3} \mathrm{SOCD}_{3}\right) \delta 63.0,124.2$, 127.2, 127.3, 138.9, 141.8, 142.4; HRMS (EI) $m / z \mathrm{C}_{27} \mathrm{H}_{24} \mathrm{O}_{3}[M]^{+}$requires 396.1725, found 396.1722.

5: A THF (60 mL) solution of triphenylphosphine $(3.6 \mathrm{~g}, 13.6 \mathrm{mmol})$ was added to a THF (60 $\mathrm{mL})$ solution of $N$-chlorosuccinimide $(2.1 \mathrm{~g}, 15.6 \mathrm{mmol})$ under an argon atmosphere. A THF (40 mL) solution of $4(0.7 \mathrm{~g}, 1.6 \mathrm{mmol})$ was then slowly added, and the reaction mixture left to stir overnight. The solvent was evaporated off under reduced pressure, and the crude product purified by column chromatography $\left(\mathrm{SiO}_{2}\right.$ : Hexanes / EtOAc, 85:15). Compound 5 was obtained as an off-white solid (500 mg, 67\%). Mp. $176^{\circ} \mathrm{C} ;{ }^{1} \mathrm{H}$ NMR (500 MHz, $\left.\mathrm{CDCl}_{3}\right) \delta 4.67(\mathrm{~s}, 6 \mathrm{H}), 7.51(\mathrm{~d}, J=8 \mathrm{~Hz}, 6 \mathrm{H}), 7.68$ $(\mathrm{d}, J=8 \mathrm{~Hz}, 6 \mathrm{H}), 7.76(\mathrm{~s}, 3 \mathrm{H}) ;{ }^{13} \mathrm{C} \mathrm{NMR}\left(125 \mathrm{MHz}, \mathrm{CDCl}_{3}\right) \delta 45.9,125.2,127.6,129.1,136.8,140.9$, 141.7; HRMS (EI) $m / z \mathrm{C}_{27} \mathrm{H}_{21} \mathrm{Cl}_{3}[M]^{+}$requires 450.0709, found 450.0714.

$[6]\left[\mathrm{PF}_{6}\right]_{3}:$ 4,4'-Bipyridine $(4.3 \mathrm{~g}, 27.6 \mathrm{mmol})$ was dissolved in anhydrous DMF (100 mL) and the solution was heated to $100^{\circ} \mathrm{C}$. To this solution, $5(0.5 \mathrm{~g}, 1.1 \mathrm{mmol})$, dissolved in anhydrous DMF $(25 \mathrm{~mL})$, was added dropwise over $2 \mathrm{~h}$. The reaction mixture was then allowed to stand for $48 \mathrm{~h}$ at $100^{\circ} \mathrm{C}$. Evaporation of the solvent under reduced pressure yielded the solid which was washed with $\mathrm{CH}_{2} \mathrm{Cl}_{2} /$ Hexanes $(1: 1,4 \times 100 \mathrm{~mL})$. The crude product was purified by column chromatography $\left(\mathrm{SiO}_{2}: \mathrm{MeOH} / 2 \mathrm{M} \mathrm{NH}_{4} \mathrm{Cl}_{\mathrm{aq}} / \mathrm{MeNO}_{2}, 7: 2: 1\right)$. The excess of $\mathrm{MeNO}_{2}$ and $\mathrm{MeOH}$ was removed under reduced pressure such that the product still remained dissolved, and a saturated aqueous solution of $\mathrm{NH}_{4} \mathrm{PF}_{6}$ was added dropwise. The aqueous phase was then extracted with $\mathrm{MeNO}_{2}(60 \mathrm{~mL})$, which was subsequently washed with $\mathrm{H}_{2} \mathrm{O}(3 \times 100 \mathrm{~mL})$, dried $\left(\mathrm{Na}_{2} \mathrm{SO}_{4}\right)$, and evaporated under reduced pressure to yield $[6]\left[\mathrm{PF}_{6}\right]_{3}(650 \mathrm{mg}, 47 \%)$ as a yellow solid. Mp. $189^{\circ} \mathrm{C} .{ }^{1} \mathrm{H}$ NMR $\left(500 \mathrm{MHz}, \mathrm{CD}_{3} \mathrm{CN}\right) \delta 5.82$ (s, 6H), $7.60(\mathrm{~d}, J=8 \mathrm{~Hz}, 6 \mathrm{H}), 7.79(\mathrm{~m}, 6 \mathrm{H}), 7.92(\mathrm{~d}, J=8 \mathrm{~Hz}, 6 \mathrm{H}), 7.95(\mathrm{~s}, 3 \mathrm{H}), 8.34(\mathrm{~d}, J=7 \mathrm{~Hz}$, $6 \mathrm{H}), 8.85(\mathrm{~m}, 6 \mathrm{H}), 8.89(\mathrm{~d}, J=7 \mathrm{~Hz}, 6 \mathrm{H}) ;{ }^{13} \mathrm{C} \mathrm{NMR}\left(125 \mathrm{MHz}, \mathrm{CDCl}_{3}\right) \delta 63.7,121.7,125.3,126.2$, 
128.2, 129.6, 132.4, 141.0, 141.1, 141.6, 144.8, 151.1, 154.6; MS (FAB) $m / z \mathrm{C}_{57} \mathrm{H}_{46} \mathrm{~N}_{6} \mathrm{P}_{2} \mathrm{~F}_{12}[M H$ $\left.-\mathrm{PF}_{6}\right]^{+}$requires 1104.30, found 1104.62.

[1] $\left[\mathrm{PF}_{6}\right]_{6}: p$-Methylbenzyl bromide $(0.26 \mathrm{~g}, 1.4 \mathrm{mmol})$ was added to $[6]\left[\mathrm{PF}_{6}\right]_{3}(0.07 \mathrm{~g}, 0.06$ mmol), dissolved in $\mathrm{MeCN} / \mathrm{CHCl}_{3}(1: 2,6 \mathrm{~mL})$. The reaction mixture was heated under reflux for 48 h. The solvent was evaporated, and the crude product purified by column chromatography $\left(\mathrm{SiO}_{2}\right.$ : $\left.\mathrm{MeOH} / 2 \mathrm{M} \mathrm{NH}_{4} \mathrm{Cl}_{(\mathrm{aq})} / \mathrm{MeNO}_{2}, 7: 2: 1\right)$. The excess of $\mathrm{MeNO}_{2}$ and $\mathrm{MeOH}$ was removed under reduced pressure, such that the product still remained dissolved, and a saturated aqueous solution of $\mathrm{NH}_{4} \mathrm{PF}_{6}$ was added dropwise. The aqueous phase was extracted with $\mathrm{MeNO}_{2}(50 \mathrm{~mL})$, and the organic phase washed with $\mathrm{H}_{2} \mathrm{O}(4 \times 100 \mathrm{~mL})$, dried $\left(\mathrm{Na}_{2} \mathrm{SO}_{4}\right)$, and evaporated to yield [1] $\left[\mathrm{PF}_{6}\right]_{6}$ as a yellow solid (40 mg, 37\%). ${ }^{1} \mathrm{H}$ NMR (500 MHz, $\left.\mathrm{CD}_{3} \mathrm{CN}\right) \delta 2.37$ (s, 9H), 5.77 (s, 6H), 5.88 (s, 6H), 7.32 (d, $J$ $=8 \mathrm{~Hz}, 6 \mathrm{H}), 7.39(\mathrm{~d}, J=8 \mathrm{~Hz}, 6 \mathrm{H}), 7.62(\mathrm{~d}, J=8 \mathrm{~Hz}, 6 \mathrm{H}), 7.94(\mathrm{~d}, J=8,6 \mathrm{H}), 7.96(\mathrm{~s}, 3 \mathrm{H}), 8.36(\mathrm{~d}, J$ $=7 \mathrm{~Hz}, 6 \mathrm{H}), 8.39(\mathrm{~d}, J=7 \mathrm{~Hz}, 6 \mathrm{H}), 8.95(\mathrm{~d}, J=7 \mathrm{~Hz}, 6 \mathrm{H}), 9.01(\mathrm{~d}, J=7 \mathrm{~Hz}, 6 \mathrm{H}) ;{ }^{13} \mathrm{C}$ NMR $(125$ $\left.\mathrm{MHz}, \mathrm{CDCl}_{3}\right) \delta 20.1,64.3,64.5,125.3,127.3,127.4,128.3,129.2,129.4,129.8,130.0,132.0,140.4$, $141.1,141.8,145.3,145.5,150.1,150.3$.

2D NMR Characterization. ${ }^{1} \mathrm{H}-{ }^{1} \mathrm{H}$ COSY and ${ }^{1} \mathrm{H}-{ }^{1} \mathrm{H}$ TROESY 2D NMR spectra $(500 \mathrm{MHz}$, $\mathrm{CD}_{3} \mathrm{COCD}_{3}, 5.0 \mathrm{mM}$ each, $\left.253 \mathrm{~K}\right)$ of $2 \mathrm{in}-[\mathbf{1} \supset \mathbf{2}]\left[\mathrm{PF}_{6}\right]_{6}$ and 3in-[1 $\left.\supset \mathbf{2}\right]\left[\mathrm{PF}_{6}\right]_{6}$ were acquired after the sample was degassed using the freeze-thaw method. See Figures S1, S2, S3, and S4.

Kinetics Measurements. The change in the ${ }^{1} \mathrm{H}$ NMR spectrum of an equimolar mixture of $[1]\left[\mathrm{PF}_{6}\right]_{6}$ and 2 , each $5.5 \mathrm{mM}$, at $253 \mathrm{~K}$ with time was monitored by ${ }^{1} \mathrm{H}$ NMR spectroscopy (Figure S5). The initial concentration of 2 in- $[1 \supset 2]\left[\mathrm{PF}_{6}\right]_{6}\left(5.0 \mathrm{mM}, 253 \mathrm{~K}, \mathrm{CD}_{3} \mathrm{COCD}_{3}\right)$ decreased wherein the concentration of 3 in- $[\mathbf{1} \supset \mathbf{2}]\left[\mathrm{PF}_{6}\right]_{6}$ increased with time. The change was quantified by integration of the bipyridinium proton $\mathrm{H}_{\mathrm{e}}$ resonances in $2 \mathrm{in}-[\mathbf{1} \supset \mathbf{2}]\left[\mathrm{PF}_{6}\right]_{6}$. When the concentration of the 2 in- 
$[1 \supset 2]\left[\mathrm{PF}_{6}\right]_{6}$ was plotted against time (Figure S6), the experimental data points were fitted to the model for a reversible first-order reaction, yielding rate constants for the forward $\left(k_{1}\right)$ and back $\left(k_{2}\right)$ reactions. ${ }^{14}$ The thermodynamic parameters $\Delta G^{\ddagger}{ }_{1}$ and $\Delta G^{\ddagger}{ }_{2}$ were obtained with the Eyring equation using the rate constants $\left(k_{1}\right.$ and $\left.k_{2}\right) .{ }^{14}$

\section{References}

(14) Espenson, J. H. Chemical Kinetics and Reaction Mechanisms; McGraw-Hill: New York, 1995; Chapter 3. 

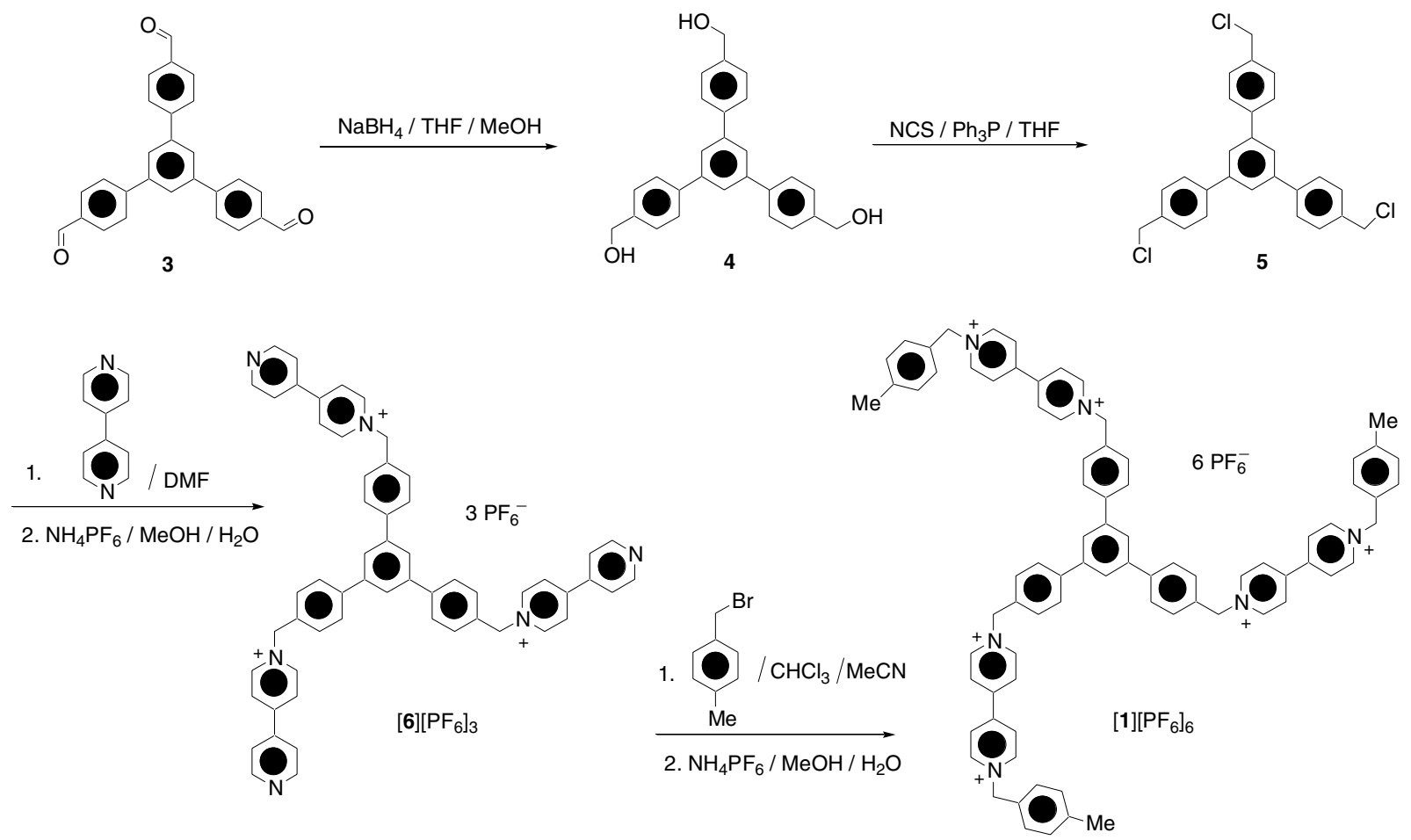

Scheme S1. The synthesis of the trifurcated trisbipyridinium salt $[1]\left[\mathrm{PF}_{6}\right]_{6}$ from 1,3,4-tris $(p-$ formylphenyl)benzene $\mathbf{3}$. 

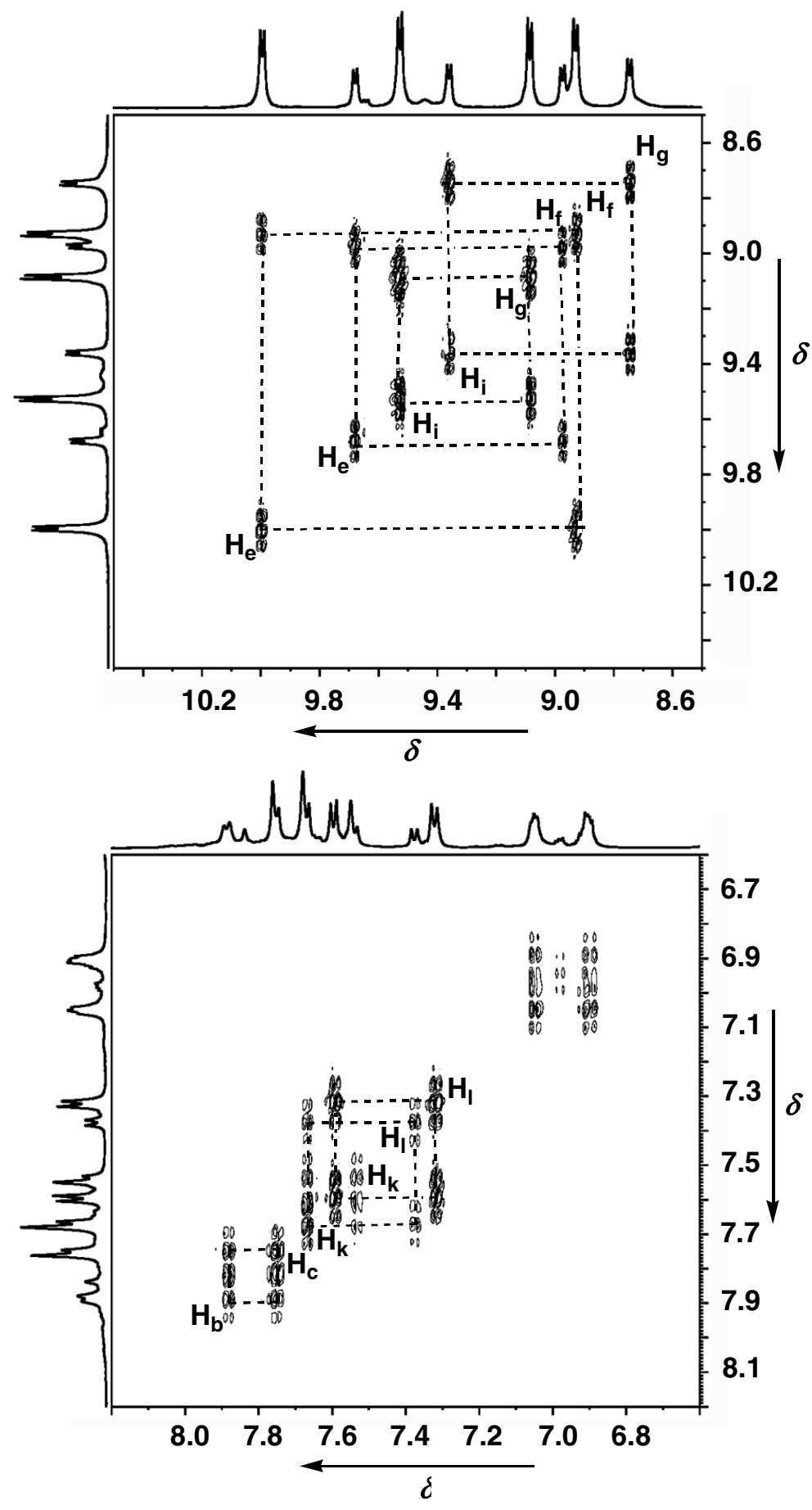

Figure S1. Selected regions of the ${ }^{1} \mathrm{H}^{-1} \mathrm{H}$ COSY $2 \mathrm{D}$ NMR spectrum $\left(500 \mathrm{MHz}, \mathrm{CD}_{3} \mathrm{COCD}_{3}, 5.0 \mathrm{mM}\right.$, $253 \mathrm{~K})$ of 2 in- $[1 \supset 2]\left[\mathrm{PF}_{6}\right]_{6}$. 

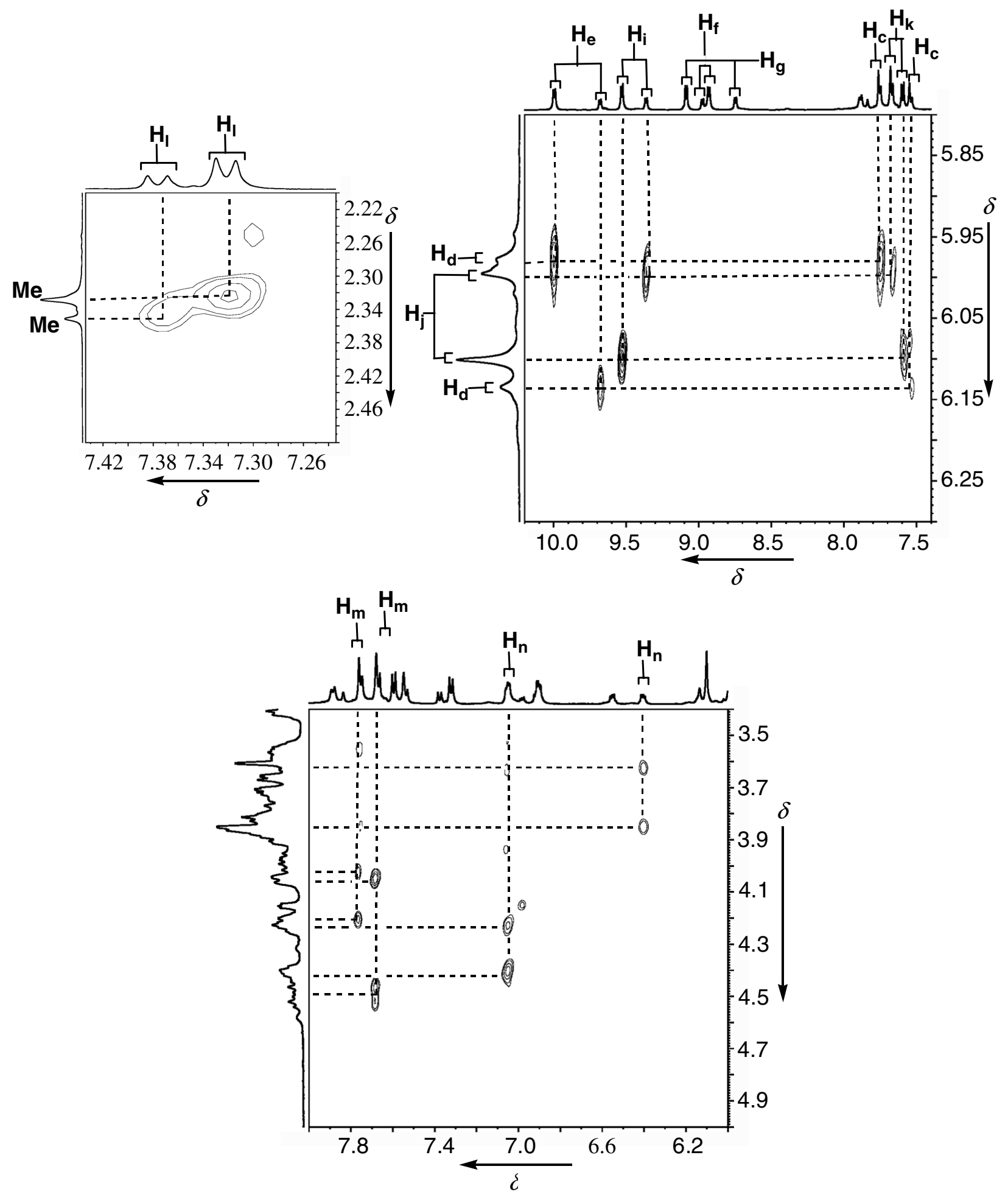

Figure S2. Selected regions of the ${ }^{1} \mathrm{H}-{ }^{1} \mathrm{H}$ TROESY $2 \mathrm{D}$ NMR spectrum $\left(500 \mathrm{MHz}, \mathrm{CD}_{3} \mathrm{COCD}_{3}, 5.0\right.$ $\mathrm{mM}, 253 \mathrm{~K})$ of $2 \mathrm{in}-[\mathbf{1} \supset \mathbf{2}]\left[\mathrm{PF}_{6}\right]_{6}$. 

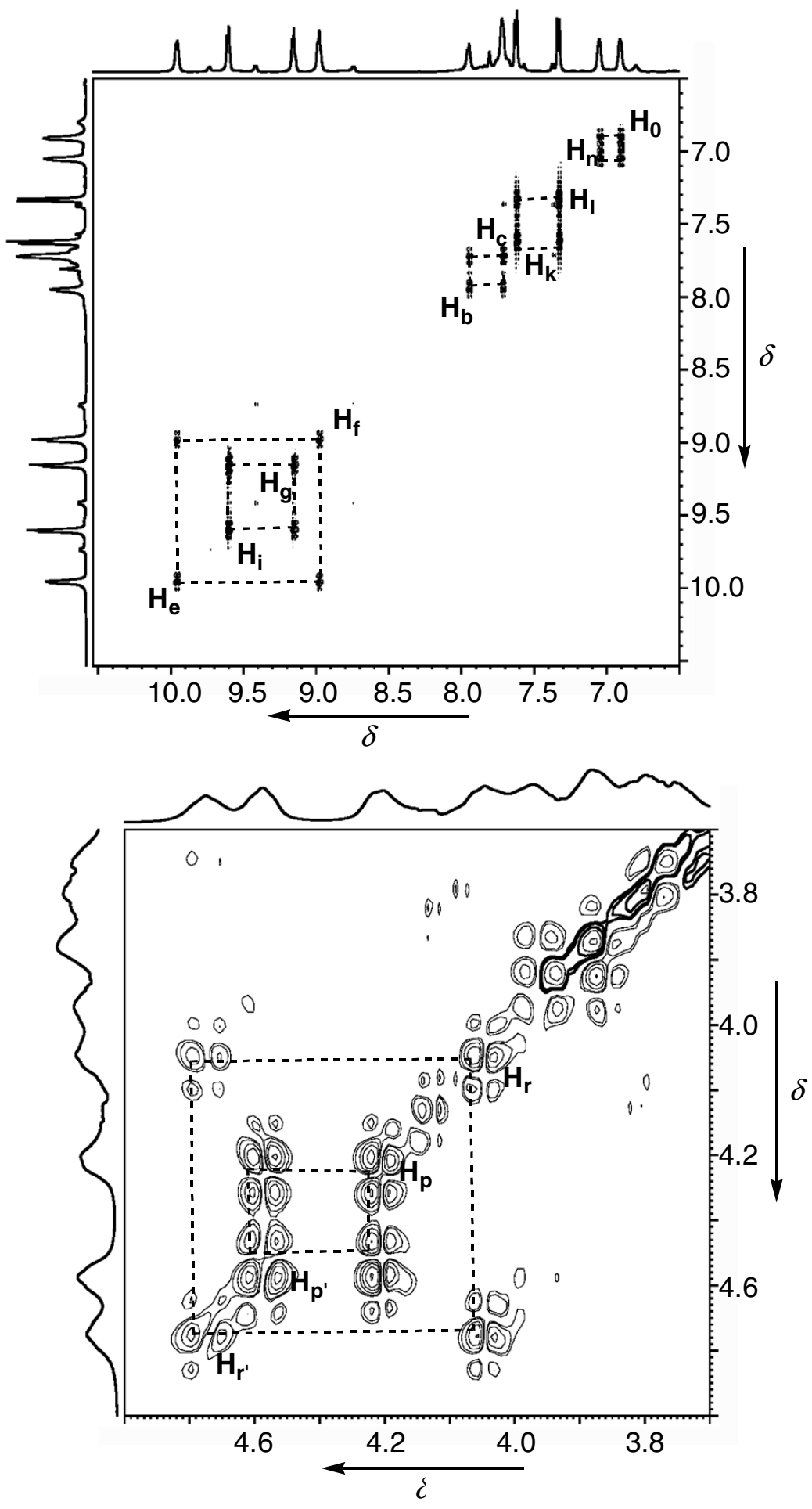

Figure S3. Selected regions of the ${ }^{1} \mathrm{H}^{-1} \mathrm{H}$ COSY $2 \mathrm{D}$ NMR spectrum $\left(500 \mathrm{MHz}, \mathrm{CD}_{3} \mathrm{COCD}_{3}, 5.0 \mathrm{mM}\right.$, $253 \mathrm{~K})$ of 3 in- $[\mathbf{1} \supset \mathbf{2}]\left[\mathrm{PF}_{6}\right]_{6}$. 

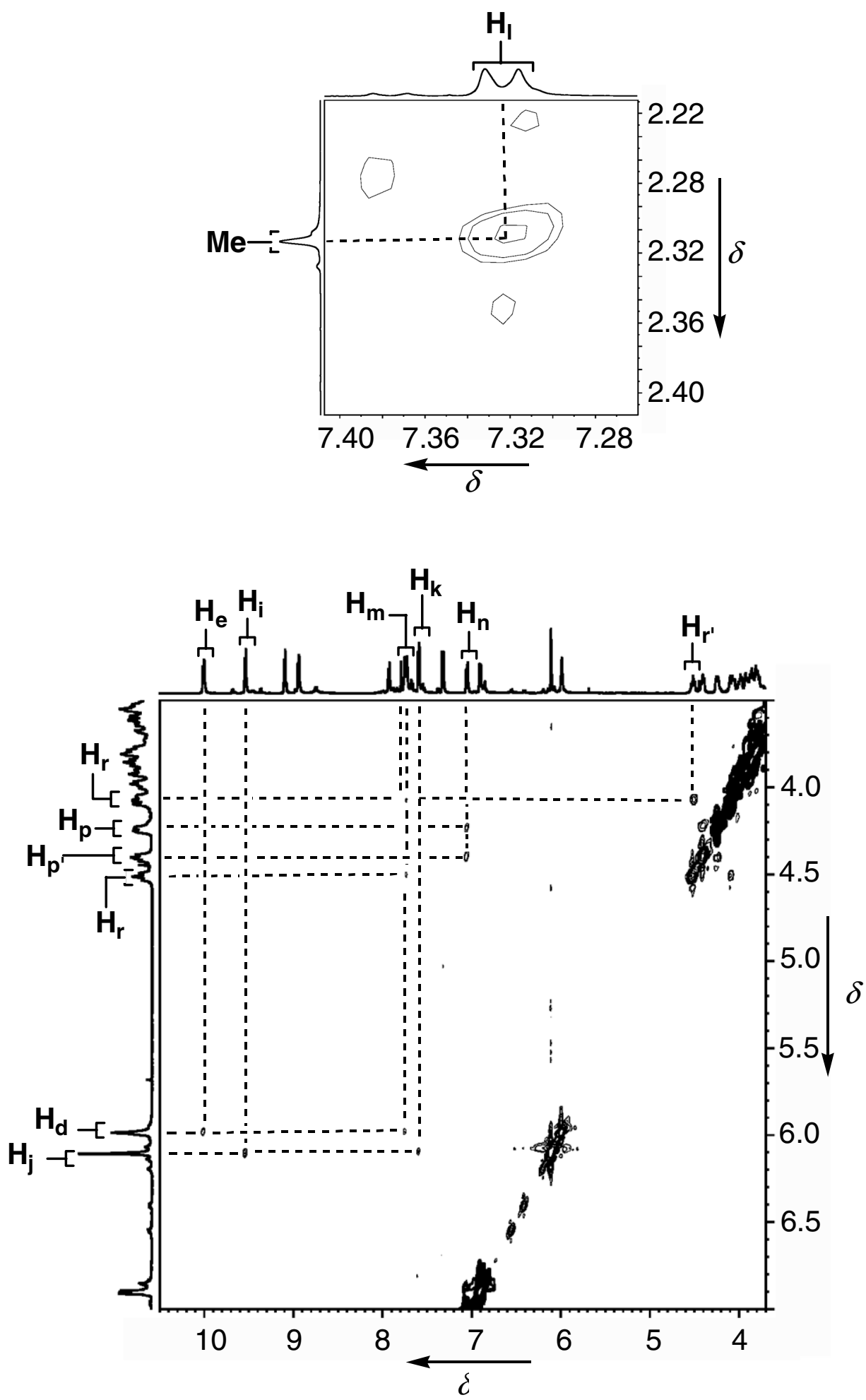

Figure S4. Selected regions of the ${ }^{1} \mathrm{H}-{ }^{1} \mathrm{H}$ TROESY $2 \mathrm{D}$ NMR spectrum $\left(500 \mathrm{MHz}, \mathrm{CD}_{3} \mathrm{COCD}_{3}, 5.0\right.$ $\mathrm{mM}, 253 \mathrm{~K})$ of 3 in- $[\mathbf{1} \supset \mathbf{2}]\left[\mathrm{PF}_{6}\right]_{6}$. 
a)

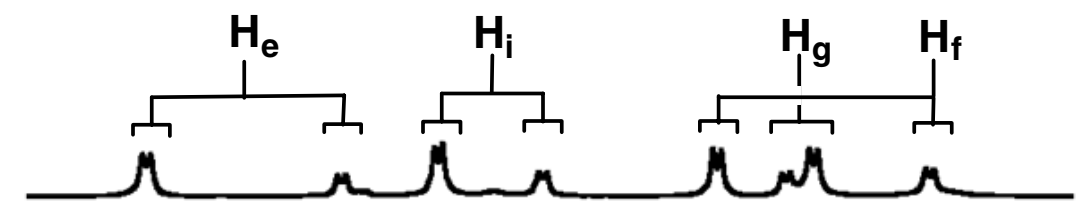

b)

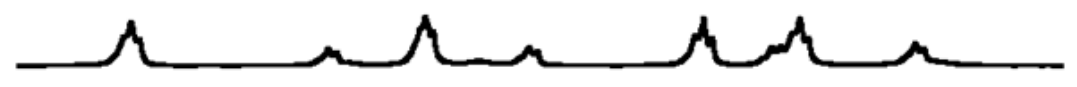

c)

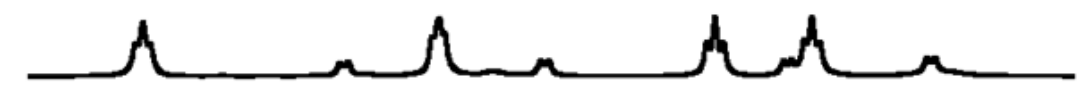

d)

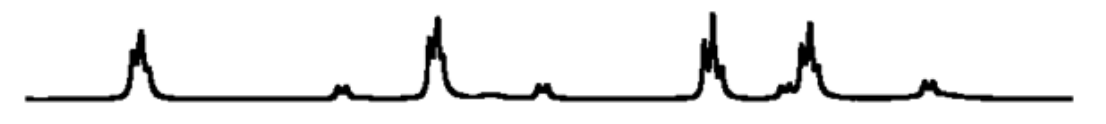

e)

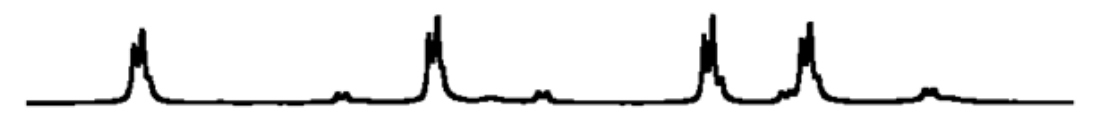

f)

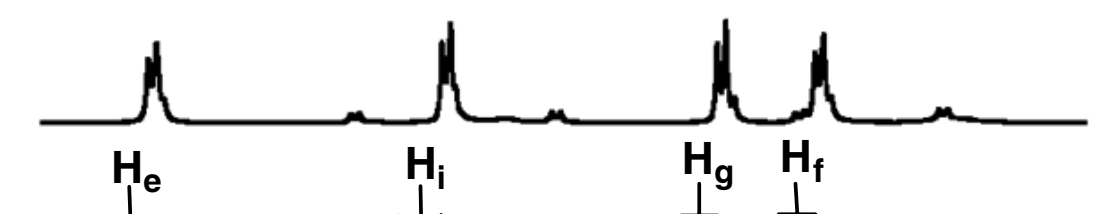

g)

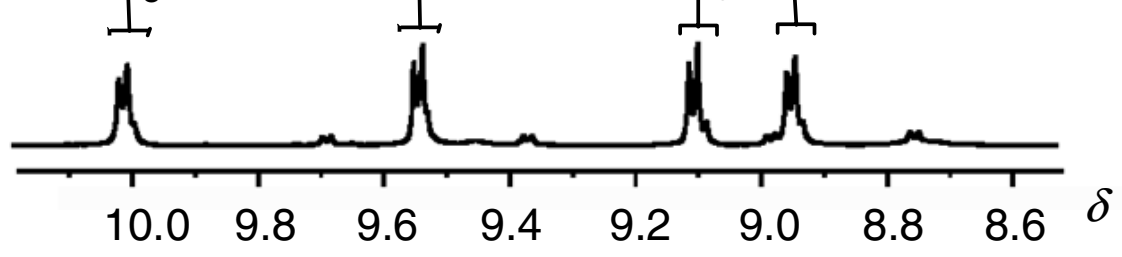

Figure S5. Partial ${ }^{1} \mathrm{H}$ NMR spectra $\left(500 \mathrm{MHz}, \mathrm{CD}_{3} \mathrm{COCD}_{3}, 5.5 \mathrm{mM}\right.$ each, $253 \mathrm{~K}$ ) of an equimolar mixture of [1][$\left[\mathrm{PF}_{6}\right]_{6}$ and 2 after (a) 0, (b) 21, (c) 47, (d) 93, (e) 143, (f) 189, and (g) $235 \mathrm{~h}$, showing the conversion of the doubly-threaded $2 \mathrm{in}-[\mathbf{1} \supset \mathbf{2}]\left[\mathrm{PF}_{6}\right]_{6}$ to the triply-threaded 3in-[1 $\left.\supset \mathbf{2}\right]\left[\mathrm{PF}_{6}\right]_{6}$. 


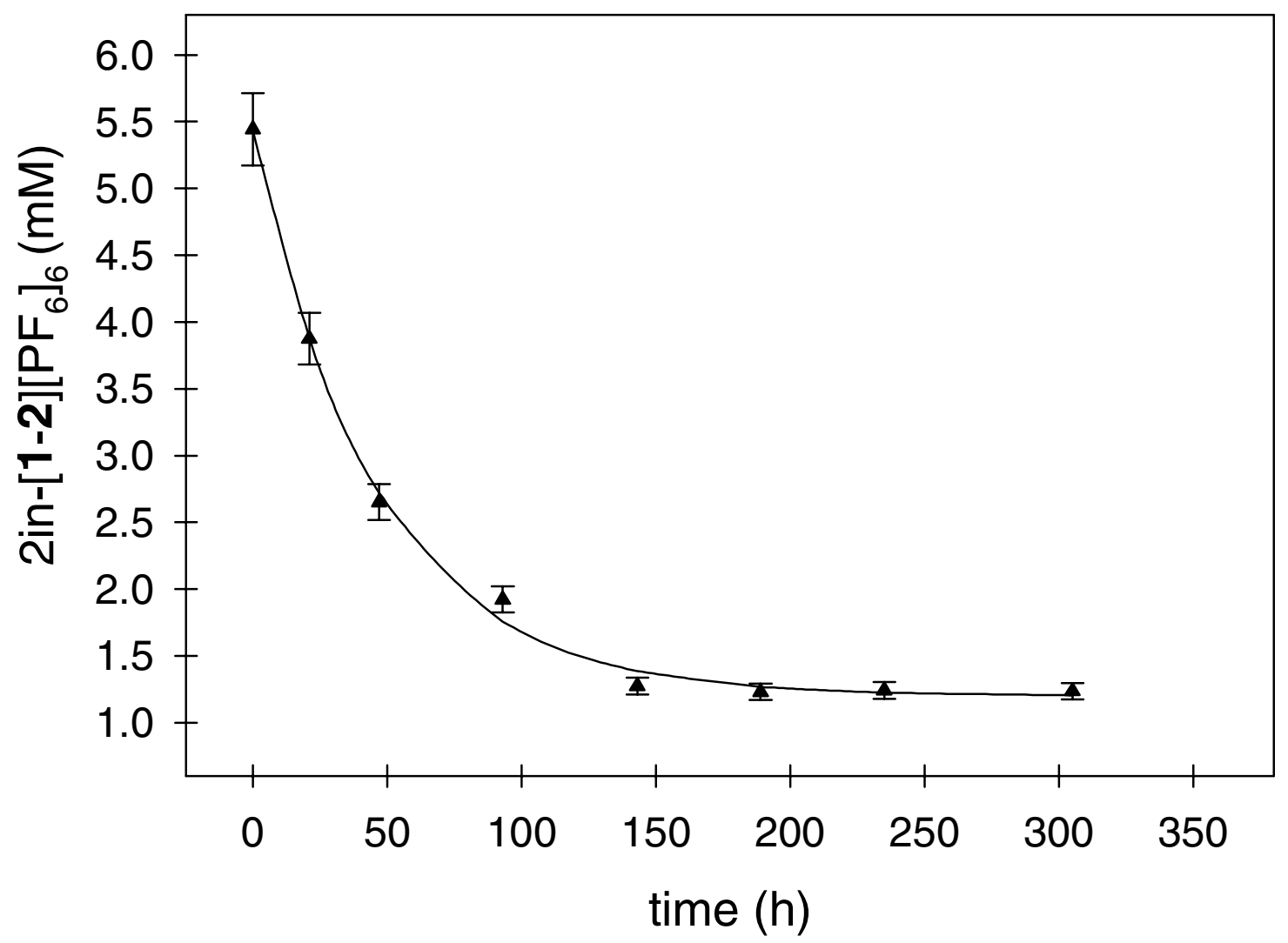

Figure S6. The concentration of $2 \mathrm{in}-[\mathbf{1} \supset \mathbf{2}]\left[\mathrm{PF}_{6}\right]_{6}$ versus time determined with ${ }^{1} \mathrm{H}$ NMR spectroscopy. Solid line is the fitting to the reversible first-order reaction law. 